\title{
Acting Bits/Identity Talk
}

\section{Gayatri Chakravorty Spivak}

In Fantasia: An Algerian Cavalcade, Assia Djebar places herself with great autobiographers: Augustine, the Berber who wrote not only his theology but his Confessions in the language of Rome; and Ibn Khaldûn, son of a family that fled southern Arabia, who wrote not only his history but his Ta'arif [identity] in Arabic. Staging herself as an Algerian Muslim woman, she gives a fragmented version of the graph-ing of her bio in French, of which I quote the following fragments:

The overlay of my oral culture wearing dangerously thin.... Writing of the most anodyne of childhood memories leads back to a body bereft of voice. To attempt an autobiography in French words alone is to show more than its skin under the slow scalpel of a live autopsy. Its flesh peels off and with it, seemingly, the speaking of childhood which can no longer be written is torn to shreds. Wounds are reopened, veins weep, the blood of the self flows and that of others, a blood which has never dried. ${ }^{1}$

Identity as a wound, exposed by the historically hegemonic languages, for those who have learned the double-binding "practice of [their] writing" $(F$, p. 181). I accept this difficult definition, to present a series of citations of "myself" engaged in identity talk.

I think one of the major motifs of Fantasia is a meditation on the pos-

1. Assia Djebar, Fantasia: An Algerian Cavalcade, trans. Dorothy S. Blair (London, 1985), p. 156; hereafter abbreviated $F$; translation occasionally modified. For details on Ibn Khaldûn, see Albert Hourani, A History of the Arab Peoples (Cambridge, 1991), p. 1. 
sibility that to achieve autobiography in the double bind of the practice of the conqueror's writing is to learn to be taken seriously by the gendered subaltern who has not mastered that practice. And therefore, hidden in the many-sectioned third part of the book, there is the single episode where the narrator speaks in the ethical singularity of the $t u$-toi to Zohra, an eighty-year-old rural mujahida [female freedom fighter] who has been devastated both by her participation in the Nationalist struggle and by the neglect of women's claims in decolonized Algeria. ${ }^{2}$ The achievement of the autobiographer-in-fiction is to be fully fledged as a storyteller for this intimate interlocutor: to tell not one's own story, but the animation of the story of two nineteenth-century Algerian prostitutes, Fatma and Meriem, included in Eugène Fromentin's Un Été au Sahara. And to succeed, for Zohra's curiosity flares up, “'And Fatma? And Meriem?' Lla Zhora interrupted, catching herself following the story as if it were a legend recounted by a bard. 'Where did you hear this story?' she went on, impatiently." The "I" (now at last articulated because related and responsible to "you”) replies simply: "I read it!' I retorted. 'An eye-witness told it to a friend who wrote it down'" (F, p. 166).

The relationship between the texts of the conqueror and the autobiographer is part of the spectacular "arabesques" of Fantasia. This unemphatic section ends simply, "I, your cousin, translate this account into the mother tongue, and report it to you. So I try my self out, as ephemeral teller, close to you little mother, in front of your vegetable patch" ( $F$, p. 167). She shares her mother tongue as instrument of translation with the other woman.

This is the divided field of identity, that a feminist-in-decolonization-as the sign of a(n) (l)earned perspective, not an autobiographical identity - can uncover between books 9 and 10 of the Confessions, in Khaldûn's "sudden . . y yearning to turn back on himself ... [to] become ... the subject and object of a dispassionate autopsy" ( $F$, p. 216).

In the rift of this divided field, the tale shared in the mother tongue is forever present (in every act of reading) and forever absent, for it is in the mother tongue. The authority of the "now" inaugurates this absent autobiography in every "here" of the book: The fleeting framed moment

2. For a discussion of the singular tu-toi in Hélène Cixous, see Gayatri Chakravorty Spivak, "French Feminism Revisited: Ethics and Politics," in Feminists Theorize the Political, ed. Judith Butler and Joan Scott (New York, 1992).

Gayatri Chakravorty Spivak is professor of English and comparative literature and adjunct professor of philosophy at Columbia University. She is the translator of Jacques Derrida's Of Grammatology (1976) and author of In Other Worlds (1987). Her two forthcoming volumes are Outside in the Teaching Machine and Identity Talk. 
undoes the "blank [blanc] in the memory" of her personal childhood, which only yields the image of an old crone whose muttered Quranic curses could not be understood ( $F$, p. 10).

The language and education policies of the French in Algeria and those of the British in India are rather different. ${ }^{3}$ The articulation of patriarchy with Hinduism and with Islam is also significantly different. Yet there is a strong structural bond between the delicacy of Djebar's staging of temporary storytelling, and my position, some nine months before I read Fantasia, lecturing in my mother tongue, in Calcutta, on the subject of "Deconstruction-Translation," in front of a university audience, many of the senior members of whom were my former fellow students. It was a situation of the public acknowledgement of the responsibility of Bengali identity among Bengalis in their felicitous habitat. Calcutta is the capital of West Bengal, the center of Indian Bengali high culture. It was also a situation of the testing of the expatriate by the locals-a presentation of an identity card as it were. The locals were ferociously well-prepared in deconstructive matters as well as its humanist critique. Any suspected patronizing (I was terrified) would have been not only an error of judgment but a betrayal precisely of the contamination of my identity by prolonged contact with the United States. (In the event, the patronage came from the other side. In the Sunday supplement of Ananda Bazar Patrika, the Bengali-language daily with the largest circulation, my identity was validated. I was hailed as a "daughter of Bengal," but also embarrassingly complimented on my control over my native language.)

For me the most interesting thing, in retrospect, about my careful exercise on "Deconstruction-Translation" was that I could get into it only by staging an error in a dictionary definition of identity, the English word. I will again turn to Assia Djebar before I advance my argument.

The final movement of Fantasia is in three short bits, what remains of an autobiography when it has been unravelled strand by strand. First a tribute to Pauline Rolland, the French revolutionary of 1848, exiled in Algeria, as the true ancestress of the mujahidat. Revolutionary discourse for women cannot rely on indigenous cultural production. If the tale told to Zohra is a divided moment of access to autobiography as the telling of an absent story, here autobiography is the possibility of writing or giving writing to the other, identifiable only as a mutilated metonym of violence, as part-object. The source is, once again, Eugène Fromentin. There is one unexplained Arabic word in the following passage, a word that means, in fact, "pen":

3. See David Prochaska, Making Algeria French: Colonialism in Bône 1870-1920 (Cambridge, 1990), and David Kopf, British Orientalism and the Bengal Renaissance: The Dynamics of Indian Modernization, 1775-1835 (Berkeley, 1969). 
Eugène Fromentin offers me an unexpected hand-the hand of an unknown woman he was never able to draw. . . . He describes in sinister detail: as he is leaving the oasis which six months after the massacre is still filled with its stench, Fromentin picks up out of the dust the severed hand of an anonymous Algerian woman. He throws it down again in his path.

Later, I seize on this living hand, hand of mutilation and of memory, and I attempt to bring it the qalam [F, p. 226].

This fragmentary finale begins with two French dictionary entries about a term signifying an item in the rhetoric of the Algerian woman's body. The entries read the figure in two opposed ways. One says that tzarlrit means "to utter cries of joy while smacking the lips with the hands (of women)." The other says that the same word means "shout, vociferate (of women when some misfortune befalls them)" (F, p. 221; my emphasis).

Structurally, although not in expressed affective character, I can find something like a relationship between this inauguration of the bestowal of writing through a European's mutilation/memory by way of an example of the limits of European lexicography and, as the second element, my own opening of the translation of Derrida's writing (on) translation by way of an example of the limits of the lexicography of English. There, women's corporeal rhetoric: tzarl-rit; here, men's transcendental logic: “identity" itself.

(I am, of course, somewhat absurdly straining to share the field of identity with Assia Djebar, rather than some identically produced, rooted Indian sister. Who, she? Is there some pertinence to the fact that what I self-cite below is an example of the very first time that I have translated my own Bengali prose into my own English? But am I not always doing that, in a way that I cannot fathom? There, then, women's corporeal rhetoric; here, below, men's transcendental logic-mistakes in dictionaries.) I quote:

In the field of rational analysis, a feeling of recognized kinship is more desirable than nationalism. Therefore I have started with the family resemblances between deconstruction and Bhartrhari-Nagarjuna. ${ }^{4}$ So that I can tangle deconstruction with our own idamvada. ${ }^{5}$ Idamvada is a weird translation of the word identity. Usually we translate identity as vyaktisatva, svarupa, ekarupata, and the like. The other day in the United

4. For a discussion of the work of these two philosopher-linguists, see Bimal Krishna Matilal, Word and the World: India's Contribution to the Study of Language (Delhi, 1990).

5. All the "Indian" words that follow are spelled according to the transcription of Sanskrit orthography, although in the Bengali pronunciation they sound quite different, and the Bengali alphabet is quite different from the Sanskrit devanägari alphabet, although descended from it. Another rift of history that English obliterates. 
States I saw in a students' English dictionary that the source of the word was given as Latin idem or Sanskrit idam and both were cited as meaning "same." Now the meaning of the Latin word idem is not exactly "same" in the sense of one, but rather "same" in the sense of multitudes or repetitions. That is to say, that which is primordial [anädi] and unique [ekamevadvitiam] is not idem, but rather that which can be cited through many re-citations, that is idem. To make these two meanings one is that clandestine patching up of a loose part of the fabric of which I have already spoken. At least from the outside it seems that in our solemn recitation of Hindutva [Hindu-ness, a key word of Hindu fundamentalism] this clan-destiny or ruse is at work. The little Sanskrit that I learnt under the able guidance of Miss Nilima Pyne at the Diocesan School in Calcutta [I beg the U.S. reader not to lose sight of the social textile here] allowed me to suspect that the Sanskrit idam is also not the undiminishing singly manifest [akshaya ekarüpa]. Then I looked at the dictionary. Idam is not only not the undiminishing selfsame, as a pronoun it does not even have the dignity of a noun, and it is always enclitic or inclined towards the noun, always dependent on the proximity of a particular self, for idam must remain monstrative, indexed. All over the world today identity politics (that is to say, a separation in the name of the undifferentiated identity of religion, nation, or subnation) is big news and almost everywhere bad news. ${ }^{6}$ The unremarkable and unremarked ruse in the United States students' dictionary [Merriam-Webster's college edition, I think] makes visible the fraud at the heart of identity politics. As a memorial to that publication I submit this outlandish deconstructed translation of identity, only for this occasion-not ahamväda [ego-ism as ipse-ism] but idamväda. Deconstruction-work shakes the stakes of the spirit's ahamväda to show idamväda, and therefore we protect ourselves in the name of a specific national identity; we do not want to know it, we dis-pose of it rather than pro-pose it. ${ }^{7}$

Here then am I, Gayatri Chakravorty (the newspaper dropped the Spivak), speaking on identity as a Bengali ("daughter of Bengal") to Bengalis. As I have remarked in footnote 5, all the terminology is general Indic (although the matrix language, here English, is Bengali) rather than specifically Bengali. (The identity of the language drops off not only in translation, but even in transcription.) I am Indian, and there is another

6. I will, later in the paper, disassociate myself from the view that U.S. multiculturalism is, according to Arthur M. Schlesinger, Jr., "the disuniting of America." See his The Disuniting of America: Reflections on a Multicultural Society (New York, 1992). In the Indian context, however, I felt that I must speak out against separatism. I am not a situational relativist. One must take account of situations because one acts according to imperatives.

7. "Pro-pose" takes me back to an earlier discussion in my paper of the famous line of Nagarjuna: "Nāsti ca mama kācana pratijnā" [roughly, "My proposition is not there at all"]. 
Bengal, the Eastern part of the land mass, another nation-state, Bangladesh. The next fragment of identity comes from Gayatri Chakravorty Spivak, an Indian in Bangladesh. The language is the same. The fragment is, in a sense, doubly cited, for it is an account of something that happened in Bangladesh that I presented at a conference on Institutions of Culture at the National University of Singapore, again an academic among academics, speaking of another place, an Asian among, largely, Asians. (A colleague from the Asian Pacific was reported as complaining, after what follows, "this sort of theory can't lead to practice." If he should read these pages, and he well might, I would gently respond that even if the relationship between theory and practice were vectored-which I cannot for a moment credit-the vector is the other way here-theory desperately attempting to digest practice.) I quote:

(Preamble-I start from the assumption that men and women occupy different positions in the making of culture. Any discussion of culture that does not take this into consideration is symptom more than explanation. Women are either silenced or ventriloquial, not-quite-subjects who hold up the culture or, if conscientized, resist.

For the last few days we have been talking about the cognitive mapping of unisex cultures. But institutions in culture must precomprehend an institution or instituting of culture, not simply as a chronologically prior event but as a philosophically subtending layer. In fact at this level, continuous with the possibility of being in the world, "culture" is one of the many names that one bestows upon the trace of being othered from nature, and by so naming, effaces the trace. This intimate proximate level is already sexed and ready for the supplement of gender, like that other most intimately distanced text of culture, the so-called experience of the inside of the body. However we narrativize the difference-deferment of cultural identity or the subjectship of culture, in this place culture is a word like value in Marx, simple and contentless, immediately codable as ground of difference.

What I have liked about Derrida over the years is the obstinate naïveté that makes him repeat the necessary but impossible questions beginning with "What is ...." The one that has engaged me most for the last couple of years is: What is it to learn? Particularly because the subjectship of ethics and the subjectship of culture, past the threshold of naming, in and out of claims to alterity, is in the hands of only those who can enter or counter globality. I am frustrated that I cannot hear the subaltern, if that is a name of culturing apart. "What is it to learn, these lessons, otherwise?" I am not interested, in other words, in legitimizing the global by reversing it into the local. I am interested in tracking the exorbitant as it institutes its culture.

This is a question I can neither answer nor stop asking. And as an 
effect of this predicament, or an adjunct to it, perhaps even a companion to it, or perhaps to shut it out, I find myself turning fragments of the institution of culture, conventionally primary or secondary, into cases. Cases of exorbitant normality rather than diseases; cases of confounding the instituted laws. I want to be able to give you four of these cases in the following pages. But let me tell you first why I think of these slippery things as cases. Because I do not want them to prove a theory by becoming post-dictions and making the theory pre-dictive metaleptically; but perhaps they do? I do not want them to be illustrations of our arguments. But perhaps they are? At any rate, these case reports inevitably produce a series of failures, working analyses and descriptions, in other words, that seem to lead somewhere.

How do I know a case is a case? Simon During asked. I cannot say, for I see a shaped outline in a fragment, it begins to make sense, and it fits into a case. And then, what is it a case of? This has not yet been a thing I have worried about in my project of unlearning learning in order to ask: What is it to learn? But, for the moment, since a question generates an answer, let me say cases of subject-ing, cases of agent-ing, thus cases of identifying, cases of the staging of culture as the originary synthesis with the absolute other; everything that we leap over when we start with the object of cultural studies or the politics of culture. But the real answer is you tell $m e$, when you have read these pages.

The first case is just an account of a conversation, a fragile exchange that I have no business setting down here.)

I was at the top of this bit of coast before I came to Singapore, on the edge of the armpit of the Bay of Bengal, the waterlogged islands of Kutubdia and Maheshkhāli and the town of Cox's Bazar, the places hit by the cyclone and tidal wave of 29 April 1991. Every act of life there is a major effort. I did not think of these efforts and encounters while I was there except to reflect repeatedly and bitterly upon the contrast between the cheerful relief and rehabilitation efforts of grass roots workers, mostly women, in the area, and the hyperreal videographic image of the absolutely abject and dependent victim. These places are not outside of globality; in another context I could tell the story of the presence there of the U.S. task force and its tremendous popular critique as one episode in a serial narrative. ${ }^{8}$

8. A popular critique quite at odds with the official view of the government. I offer here an excerpt from my personal copy of a long letter written on 6 June 1991, to the Commander of the Joint Task Force by the Sub-Zonal Relief Coordinator. (The only airconditioned interior I entered in the area was the spacious room of the old British Circuit House, now his office.)

Excellency, as you passed from bondage to freedom and independence, we passed from independence to slavery and bondage, and we were a nation lost. It was through and after long years of struggle and sacrifice that, we were finally able to throw off our chains and fetters. Today, democracy in our country is reborn. It is young, hardly a few 
When I returned to the capital city of Dhaka, Farhad Mazhar, a male activist, a pharmacist-poet who knows his Marx and Hegel, asked me: "What did you see?" I had not thought of this yet. But, since a question generates an answer, I scrambled to legitimize myself with this man of work. Beside me were sitting a woman, a high school graduate from a country town who is a teacher at a barefoot school (not a player in the culture of the coastal islands), and a woman law graduate, considerably more articulate but less of a worker, just beginning to worry about the problems of Bangladeshi rape law. I knew that what I was saying was over the women's heads, and it was my problem, not theirs. But the case got made nonetheless.

I had seen, I said, that life and death are in the rhythm of water and land for these coastal peoples-I implore the U.S. reader not to confuse this with an identikit for all Bangladeshis - and not only for the very poor among them. They build in the expectation of obliteration, planned obsolescence at the other end. Everyone, including the health and relief workers from other parts of Bangladesh, half a notch above the lowest of them in class, remarks on the fact that loss of land and kin seems to leave a noticeably impermanent mark on the inhabitants of this area. Yet they are not "fatalists," they grieve and want relief, to rebuild in the face of certain loss, yet again. This is an eco-logical sense of being-in-the-world. The way I found myself putting the case was in terms of the young Marx's perception of species-life rather than species-being, where human life and death

months old. But within these few months it has had its baptism of fire, with the fateful and devastating Cyclone and Tidal surge of 29 April, 1991, which rocked our people to their roots and caused devastation on a scale hitherto unknown, and left them in a state of complete shock and bewilderment.

But our people are resilient, they are born in cyclones and tidal bores, and they grow and live with them. For them, cyclones and tidal bores are almost so to say a natural habitat. With fortitude, and indomitable courage our people withstood the scourge of the cyclone which was like a holocaust. Inspiration and unshakable assistance from friends like you helped to get us back on our feet sooner than later, and move boldly ahead. You and your sea angels, helped, facilitated and expedited the process of our recovery. For this, we will remain indebted. We have no words adequate to express our gratitude.

But above all, it was your conduct your Excellency, which perhaps was the wellspring of inspiration and hope. Your memorable words still echo and ring in our ears. These have left an indelible imprint on hearts and minds. You likened democracy in our country to a young plant which needed extreme care and attention to flower and blossom. You had as you said, come to nurture and water the roots of this young plant, for according to there could be no humanity without democracy. Your words and action have once again, convinced us that our road to progress and development was only one- the road of democracy.

No comment is surely needed here about the fracture between claimed "national identity" and the alignment with another "nation" - the United States-on the one hand and beingin-the-land on the other. 
is no more than Nature breathing in and out. ${ }^{9}$ Marx was obliged to narrativize the case in both a logical and a historical way: for him, both logically and historically, this space was a determination where revolution or planning would not take. And in the understanding of history as sequence, knowing how to help presumed knowing what should be wanted, easier within a mere scientific vision of the formation of class, but not possible on this coastline. Here the cultural rather than the class subject was repeatedly being instituted, or instituting itself in an eco-logy, a logic of a greater household or oikos, where the subject of the logic is not necessarily "worlded" as human in the common individualist sense. For my interlocutor, Mazhar, this was proof that, after the critique of consciousness as appropriation, Marx had not theorized property adequately, and that the task of alternative strategies of development that respected subaltern agencies of the institution of culture is to learn to rethink property. I had no such confidence; I was stalled at "what is it to learn" and offered a contradiction that I had also seen.

If this was an eco-logic where the unlikely material subject was the pulse of the tide and the rhythm of the waterlogging of wind, I was in no way ready, daily encountering these very people's savvy discussion of the U.S. task force-that had taken its helicopters back home, that had dropped supplies already available and moving "in much larger quantities" in the slow-moving trawlers, that had created more trouble in their medical facilities because they could not communicate, that had been contemptuous to the locals, all comments heard from these very peoplesimply to narrativize them as an earlier pre-scientific stage where the proper help was to control nature so that these people could be redefined as passive and graduate to a more or less remote commitment to, or critique of, capitalism. What would it be to learn otherwise, here? Better offer the contradiction: they will not move except as unwilling refugees.

It is commonplace now to say that the expansion of colonialism transformed habitation or land from its status as reference for the dominant subject, so that space could become a signifier for the colonizer: and through "nation" into empire. It is becoming commonplace to say that, for the migrant or nomad or yet hybrid, land or space is now being transformed into a script or graph, not a containing system of signs. Smadar Lavie has written on Israeli holding action, in the face of this script, energetically defining an "identity" for the Bedouin, that master nomad, since the late sixties. ${ }^{10}$ But this tenacious clinging to land seemed something else: a postponement of the eco-logic that otherwise instituted the cultural moment for these people. What was it to learn to help, here? I could

9. See Karl Marx, Early Writings, trans. Rodney Livingstone and Gregor Benton (Harmondsworth, 1975), p. 328.

10. See Smadar Lavie, The Poetics of Military Occupation: Mzeina Allegories of Bedouin Identity under Israeli and Egyptian Rule (Berkeley, 1990). 
respect the relief workers' bemused on-the-spot decision that this other kind of resistance to rehabilitation must not be allowed to develop into an aporia. The work of rehab must continue. But with the vestiges of intellectual sophistication I possessed, I saw through with distaste the longdistance theorist's dismissal of the aporia as anachrony or his embracing of it as the saving grace of a-chrony. I was adrift. I knew the ways of cutting the drift or dérive, of course. Silence the subaltern by talking too much. Describe, account, print.

I cannot close this case. I will go back, asking again: "What is it to learn?" In a minute I will make an enormous leap into the much more comfortable and recognizably political arena of the institution of culture in hyphenated art in the First World: Lebanese-Canadian. But I cannot leave this case without reminding myself that even in this liminal culture, by religious naming, Muslim-Hindu and Buddhist, women have an ironic relationship to both eco-logic and the positing of land as its postponement. In exogamy, these women shift their loyalty from father's land to husband's, quite as our female colleagues do. In reproductive culture, these girls' knees scissor in at adolescence and slowly open wider and wider as the rhythm of childbearing in the rhythm of tide and wind is seen as the definitive predication of gendering. Perhaps deconstruction rewrites Marxism for me by the fearful sense that even species-life, the Realm of Freedom, Stoffwechsel as Marx called it, or material alteration of nature, cannot be without gendering if disclosed in the institution of culture. The move into globality here is either the utter dehumanizing of reproductive engineering or the processing zones of post-Fordist export. Chittagong, the biggest town in the area, is also a port. There are plans to transform Cox's Bazar into a serious port as well.

If the previous part was written in the wake of the U.S. task force, the following bit was written in the shadow of a war as intercultural performance, where an old politics of identity successfully managed an absolute politics of culture.

In February of 1991, I was in a pretty villa on Lake Como, owned by the Rockefeller Foundation, where I hope to be again. We were conferring on intercultural performance. I flew back to Toronto, to read a paper, on my birthday. I was musing on identity, thinking that my entry into identity had been "experienced" by my mother as pain, relief, attachment; that the famous birth trauma, opening the ontic, remained inaccessible to "experience," to onto-logy as auto-bio-graphy. I was considering how powerfully this is used for an ethics of sexual difference by Luce Irigaray in her "Fecundity of the Caress." 11 The man behind me started up

11. See Luce Irigaray, "The Fecundity of the Caress: A Reading of Levinas, Totality and Infinity, Section IV, B, "The Phenomenology of Eros," in Face to Face with Levinas, ed. 
a conversation. He told me with considerable relish that we had started the ground war in Iraq.

I felt the force of that shared "we" so strongly that I knew that I would start with talk of war that evening in Toronto. This identification, in the most colloquial sense, can only be described through the political affect of the green (no longer phenomenally so) or alien registration (identity) card-an unnameable identity, named only as "alien," yet strong enough, again, for public self-identification with protesters in the nation. I quote:

I have been struck by the extent of a certain kind of Judeo-Christian religiosity and patriotism on both sides of the war in the United States: Because we are good Jews and good Christians, and because we are Americans, we must punish Saddam for misbehaving and kill the people of Iraq; or, because we are good Jews and good Christians, and because we are Americans, the people of Iraq are our brothers and sisters, however devilish or clownish Saddam might be.

To put it in code: "legitimation by reversal," of a war, of the new imperialism. Millennially, whenever there has been a certain kind of classic victory, the imperialist powers have reshuffled what remains in order to create a new empire. The apparent winning of the cold war and the dissolution of the Warsaw Pact had to be organized by the United States so that the positions could be reshuffled, so that we could have a new world order before the European Economic Community could become the United States of Europe.

In the context of the Eighteenth Brumaire of the Bolshevik Revolution, these words relating to cultural politics are already out of date. Economic abstractions have a slower tempo, and hence the following passage still retains a certain pertinence:

The Western powers will be kind enough to destroy their lands, and those whose lands are destroyed will be made to pay the cost of destruction. But the Western powers will be equally kind enough to engage in the reconstruction of the prostrate, devastated lands, for which the victims of devastation will have to fork out money a second time around.... The opportunities, as currently assembled, are so tempting that a scramble is already on among contractors and engineers hailing from different Western countries. They have not the least doubt that whatever the temporary difficulties, that beast,

Richard A. Cohen (Albany, N.Y., 1986), p. 232. 
Saddam, is bound to receive his just deserts, and Kuwait and its oil will be regained for the West. ${ }^{12}$

The most frightening thing about imperialism, its long-term toxic effect, what secures it, what cements it, is the benevolent self-representation of the imperialist as savior.

Therefore, listening to the United States protest movement as well as the voice of the new patriotism, some noticed how difficult, even impossible, it would be to transform that cement into an international voice that acknowledges global cultural diversity with respect rather than mere benevolence. Some were reminded over and over again of the lessons that we learned in our lives, about the sense of mission that secures and cements imperialist victories in the economic and the political fields by persuading the victim to produce assent.

What we call experience is a staging of experience, sometimes on the small screen. In this sense, an earlier experience is being staged in this new, displaced imperialist scene: the horror of an absolute act of intercultural performance. One of the many tasks of the activist intellectual is to offer scrupulous and plausible accounts of the mechanics of staging. A most tenacious name, as well as the strongest account of the agency or mechanics of the staging of experience-in-identity is "origin": "I perform my life this way because my origin stages me so." National origin, ethnic origin. And, more pernicious: "You cannot help acting this way because your origin stages you so."

The notion of origin is as broad and robust and full of affect as it is imprecise. "History lurks in it somewhere," I had written, but now I think that sentence would have to be revised: History slouches in it, ready to comfort and kill. Yet to feel one is from an origin is not a pathology. It belongs to that group of grounding mistakes that enable us to make sense of our lives. But the only way to argue for origins is to look for institutions, inscriptions and then to surmise the mechanics by which such institutions and inscriptions can stage such a particular style of performance. This preserves and secures the minority voice in Anglo cultures and also reveals the manipulation of the very same minorities into superpower identification in the violent management of global cultural politics.

In a crisis the intellectual as activist does not always stop to divide a fully mobilized unity. Stands get taken on both sides because, at ground level, democracy is counting bodies-the more the better. That is how changes in agency are inaugurated, higher lawmaking is pushed by bodies mobilized into "the same voice." At a moment of crisis one does not speak up against the absolute intercultural translation that may be cementing both protest and blind patriotism. Even if one knows from the staging of the experience of history that this absolute interculturalism is also that

12. A.M., "Calcutta Diary," Economic and Political Weekly, 23 Feb. 1991, p. 403. 
which cements imperialist malevolence, one does not speak up, one joins. In a crisis, no hand is clean. Analysis is action there, performance is art. One does not speak of art there as a specific terrain, and does not mention the possibility that rights as written by Law are not "experienced" as such by an individual-in-identity, but rather animate an abstract agent-inexperience.

When I speak of art specifically, away from the scene of crisis, my take is a schoolteacher's take: art and literature and music for me are audiovisual teaching aids in the construction of cases. Naïve but useful if one is groping to state the question: what is it to learn? In this view, art also performs the short-haul/long-haul two-step I have just described in terms of the performance of protest. The videographic performance of war and its aftermath pretends to be analytic as well as performative. It tries to fluff the important difference and relationship between the short haul joining together for body count and the long haul speaking up to displace the legitimation by reversal.

Let us now consider a few bits of visual production that intervene in various ways to confuse the possibility of an absolute translation of a politics of identity into cultural performance. In doing so they blur the identity among minority voices without creating a monolithic solidarity. Let us consider a piece by the Lebanese-Canadian artist Jamelie Hassan. We will look briefly at her installation called Midnight's Children, part of a mixedmedia show called Inscription. ${ }^{13}$ This particular installation is a treatment of Salman Rushdie's novel of the same name. In this particular installation Hassan powerfully wrenches the title of Rushdie's novel from its context. She is working to confuse the possibility of absolute translations, in the field of identity as well as performance.

Like Rushdie, I am from the Indo-Pakistani subcontinent. We are, then, talking about my own context, productive of my own identity as decolonized subcontinental. I applaud Jamelie Hassan's feeling for "becoming involved and taking a stand on issues that may not necessarily affect you directly," especially in the face of the fierce turf battles in radical cultural studies in multiracial cultures as well as on the geo-graphed globe, where the only possible politics seems sometimes to be the politics of identity in the name of being the Other. ${ }^{14}$

But, although I applaud this, Midnight's Children is on my own turf. By relocating it, Hassan puts my own identity in parentheses, shows that

13. The following seventeen paragraphs are excerpted and modified from Spivak, "Inscriptions of Truth to Size," in Inscription (exhibition catalogue, Dunlop Art Gallery, Regina, Saskatchewan, 15 Sept.-21 Oct. 1990), pp. 9-11, 14-15.

14. Hassan, quoted in Inscription, p. 18. On the situation of current identity politics, see Edward W. Said, “The Politics of Knowledge," Raritan 11 (Summer 1991): 17-31. I remain saddened by his impatience with deconstruction and his refusal to understand the robust sense of "text." I have written so much about it elsewhere, that I will simply record this melancholy here. 


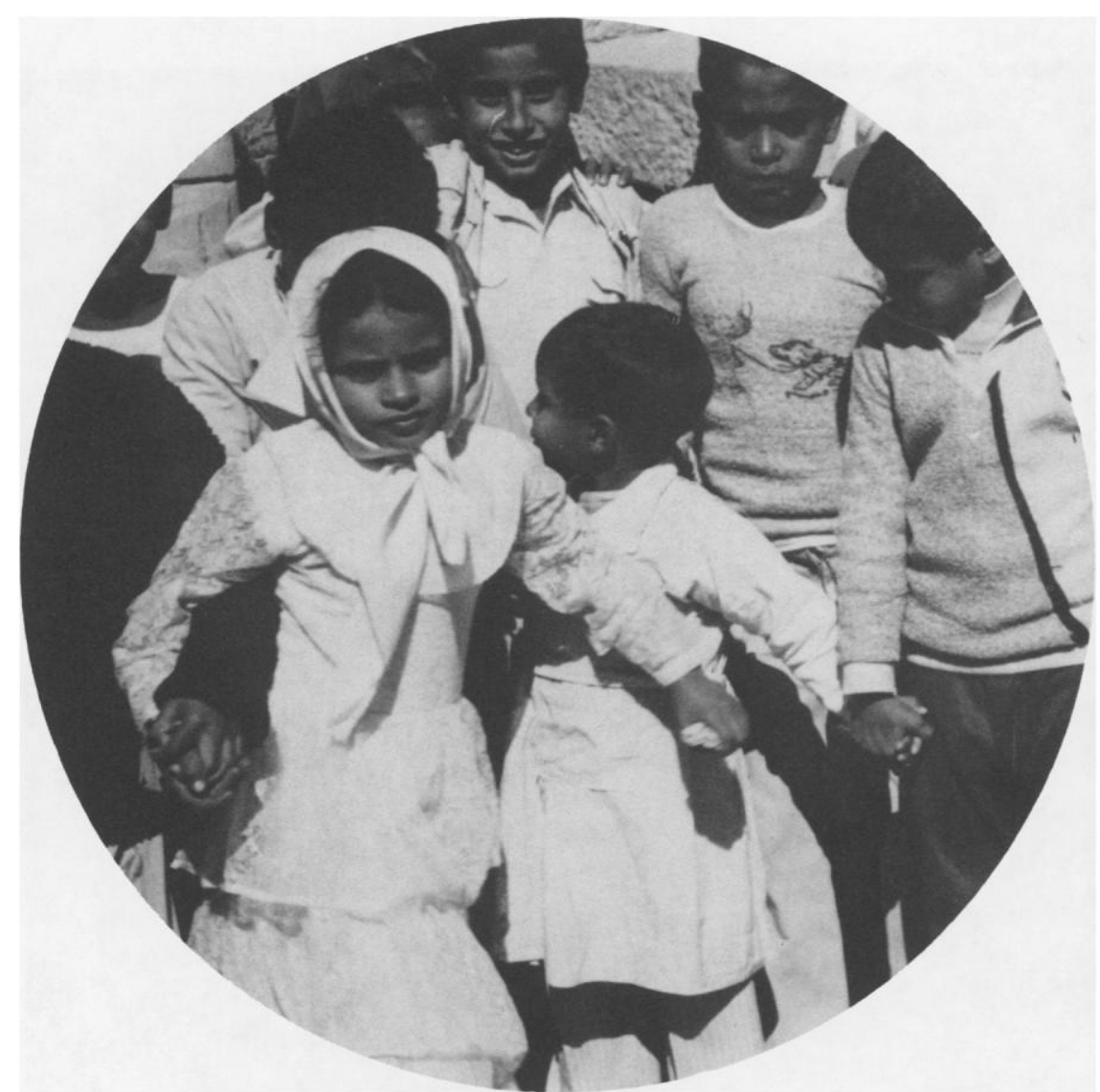

FIG. 1.-Jamelie Hassan, Midnight's Children. Detail. Photo: Jamelie Hassan.

"my" context is also unsaturated and open, like all contexts. The effort at fracturing my identity is precisely not to sanctify the memory that I was awake, as a child, on that midnight, between the 14th and 15th of August 1947, when an India divided into India and Pakistan became independent. Hassan makes me learn the ropes. She has unmoored the date, away from Rushdie's India and Pakistan, and given it over to the children of Egypt - who seem, to most sympathetic spectators in North America, and they are in a minority, to be the children of Palestine. And I say, it's all right.

On the wall, flanked by the photographs of children, is a large brass plate by Aly-Aly Hassan, an Egyptian artisan, inscribed "Midnight's Children" in English and Arabic, with "Salman" in Arabic in the center. The final sentence of Midnight's Children, written in a spiral on the wall, now speaks the fate of the dispossessed children who lost their country in 1948, 


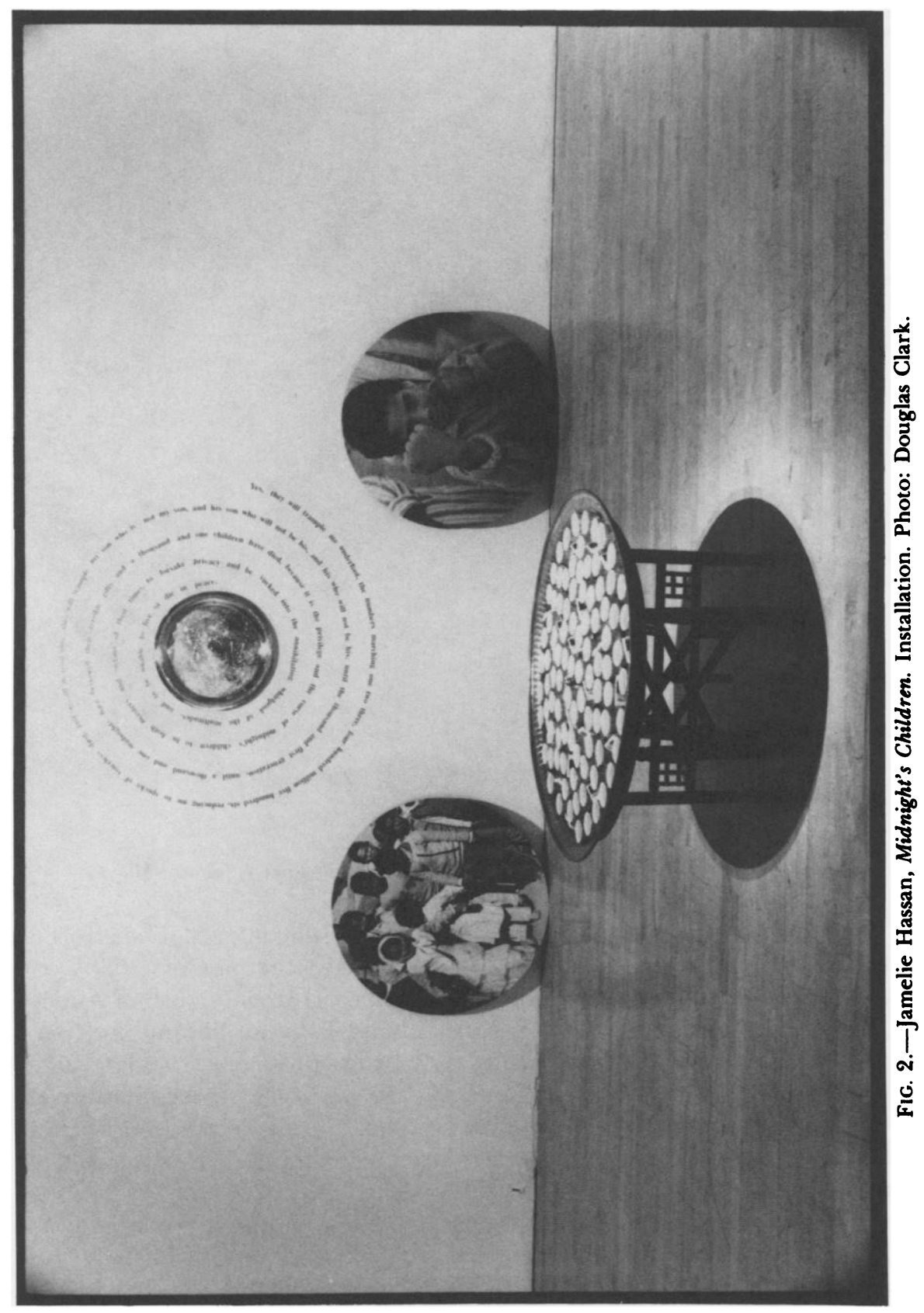

This content downloaded from 128.59.161.126 on Fri, 13 Mar 2015 18:12:31 UTC All use subject to JSTOR Terms and Conditions 
although neither photograph nor novel represents them, since the children in the novel are Indian and Pakistani citizens, and the actual children in the photograph are Egyptian. This is a strange feeling that you may not share unless you are subcontinental by "origin." In the staging of my identity, the idea of that midnight is solidly established as historically belonging only to my own access to postcoloniality. This, after all, is a more publicly accessible field of self-recognition than standing before my classmates, our teachers, and their students, in my hometown, speaking in the mother tongue about uneasy Theory, or hanging out in wind and water, learning not to transcode too quickly. I stood in front of the installation stripped, precisely, of my "identity." This is the kind of stripping that must be undertaken together if ethnic identities in the so-called First World are to become culturally and politically productive.

A year later, having had my first lesson, I was adrift in Djebar.

This is the constructed base from which one can emphasize the new American and place her with the Africans and the American nations that built today's America in unacknowledged blood. To create the new American out of the pipe dream of "We, the People," or out of the bogus concept of the world's policeman, or to give democratic ideals a kind of moral luck is to forget the violence at the origin. When we engage in identity turf battles, we forget this unacknowledged heritage; we accept the staging of the U.S. as enlightened white and behave as if the ethnic scene in the United States represents the globe. This representation is a version of the dream of white America.

Think of it this way: what we call culture, at many removes from that vestigial originary space I grappled with in the case of coastal Bangladesh, may be shorthand for an unacknowledged system of representations that allows you a self-representation that you believe is true. Then the culture of the United States, even before the establishment of the United States as such (the kind of place that, say, Goethe looks forward to at the end of Wilhelm Meister, the dream of old Europe come true) is, in that understanding, the dream of interculturalism: benevolent, hierarchized, malevolent, in principle homogenizing, but culturally heterogeneous. And that particular hegemonic U.S. cultural system of self-representation, abundantly available in and for the socius, begins to usurp, for the U.S., the entire globe. And the fact that every national origin is written with a hyphen before the word American tends to get forgotten. The next step is Arthur Schlesinger and Lynne Cheney, armed with The Disuniting of America. But not every artist performs that way.

Here is another example from Jamelie Hassan's work that represents the new American, speaking. I want to walk over to another installation piece called Meeting Nasser.

Jamelie Hassan, whose parents came to Canada in 1914 and 1939 from Lebanon, grew up in an Arabic-speaking household. Yet she is not 


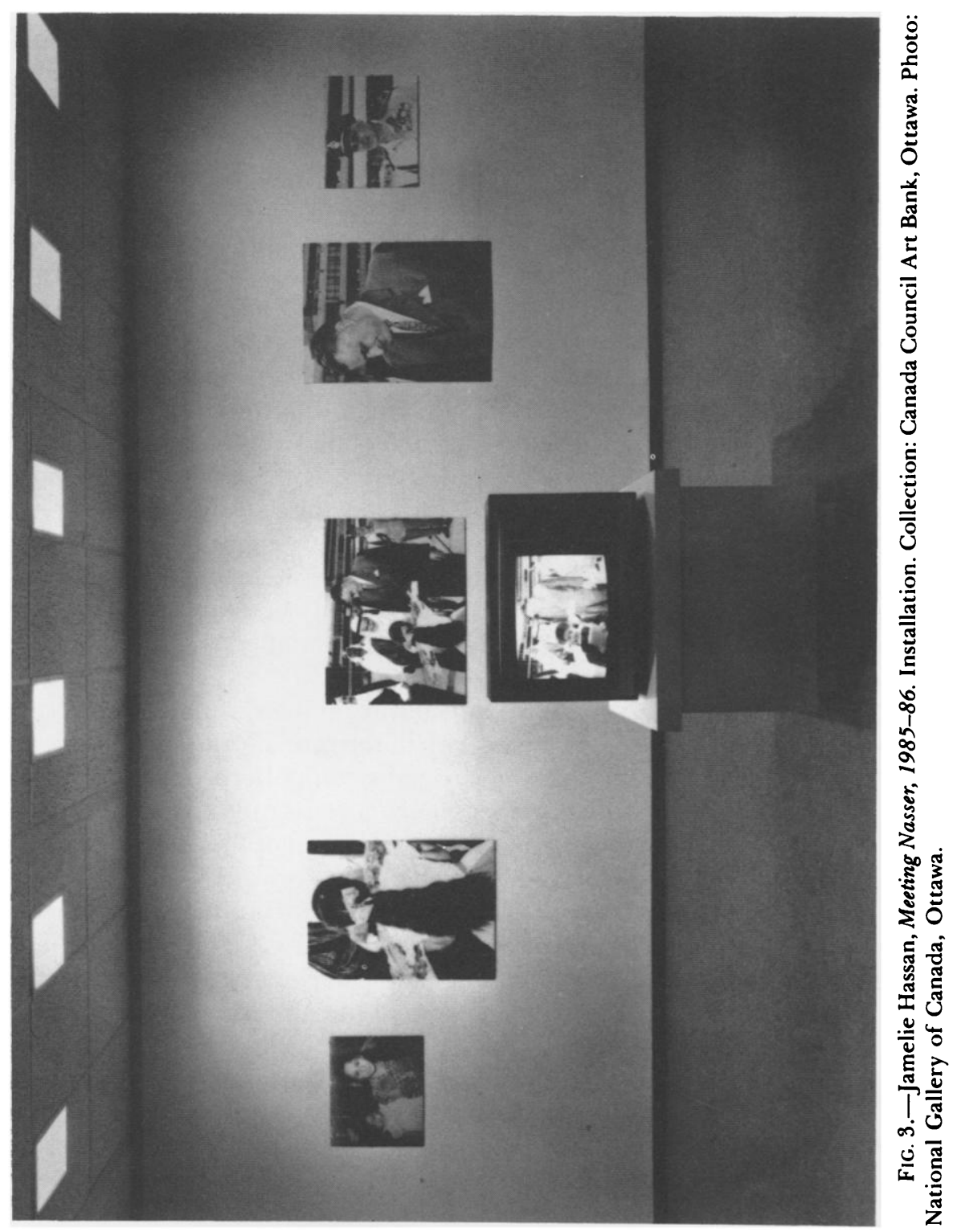

This content downloaded from 128.59.161.126 on Fri, 13 Mar 2015 18:12:31 UTC All use subject to JSTOR Terms and Conditions 


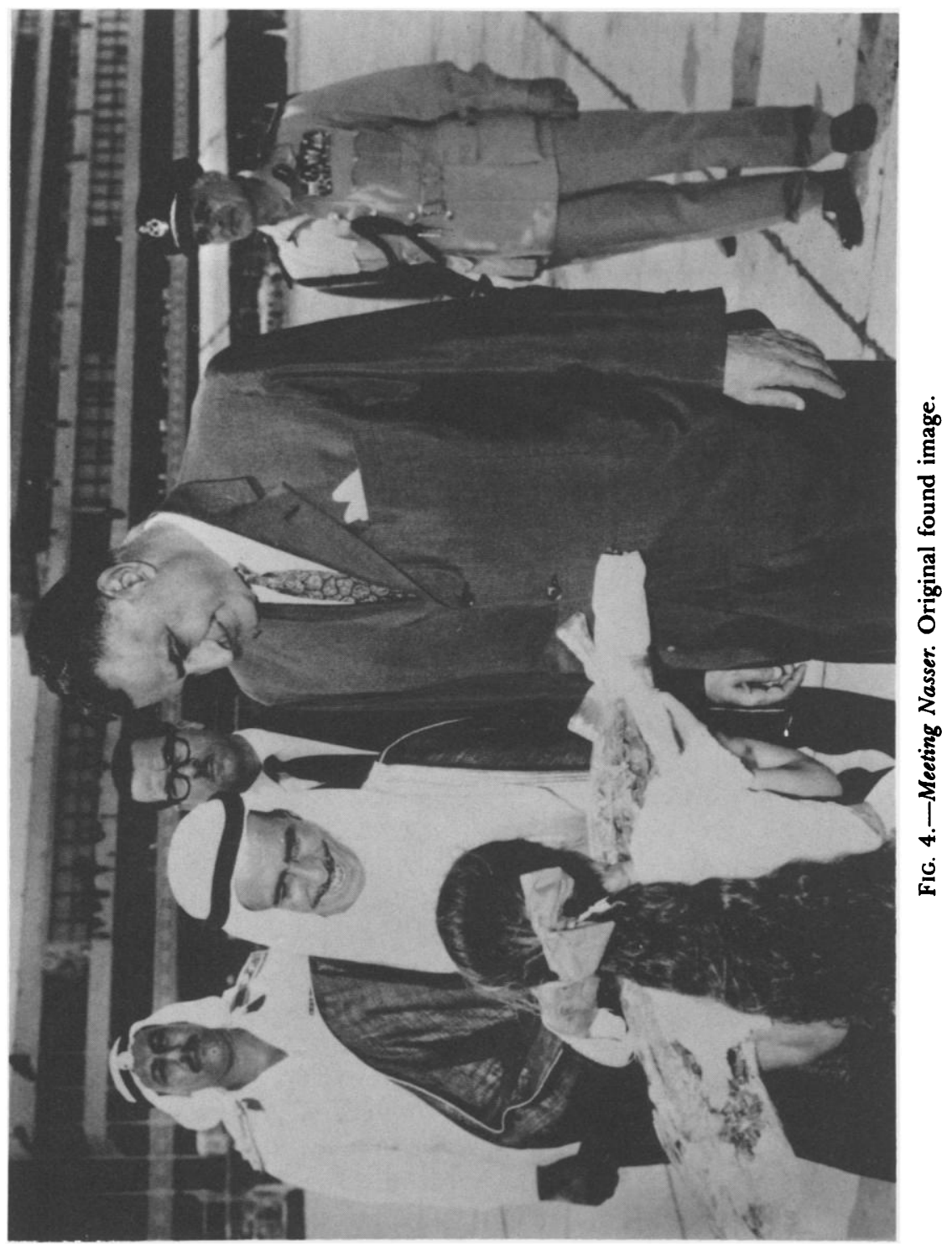

This content downloaded from 128.59.161.126 on Fri, 13 Mar 2015 18:12:31 UTC All use subject to JSTOR Terms and Conditions 
merely nostalgic about her place of origin. She sees it as a place in the history of the present, not just in the history of her own displaced migration. This installation is a "texting"-a weaving, as in textile-of that seeing. Hassan sees the place of Gamal Abdel Nasser, the "liberator" of Egypt, through the writing of Naguib Mahfouz, one of the writers censored by him. The child in the video monitor in the installation reads a passage from Mahfouz, on censorship, in English translation.

This is a text about the restitution of truth to history through rememoration. Because Hassan recognizes the place of origin as a place other than simply an endorsement for herself as cross-cultural North American Other, she can respect the immigrant as agent of historical rememoration. The immigrant is becoming the agent of the history of the metropolitan country in the coarse grain of the law as well as in the paradox of language. The photographs lining the walls in this installation were found in her family album. An extremely strong statement of the politicization of the personal.

Who is the little girl presenting the bouquet to Nasser in the blown-up photo on the wall, overshadowed by grinning men? Is it a younger Jamelie Hassan? We cannot know; nor can she. All we have is another blown-up snapshot on the wall, of herself full face, without Nasser.

With Nasser the little girl's back is turned to the camera: a simple sign-nothing as heavy as a metaphor or a symbol_of the recovery of identity in politics, or the loss of reference in the graph. You cannot have a true fit of identity in the political. The little girl with Jamelie and the little girl in the picture are not the same, just the approximate size, a hand-me-down, to others who must stage the same collective origin as yourself.

The video monitor mimes the scene or stage of the writing of history. This girl, dressed quite like the girl in the photo, faces us. She is Elizabeth Hassan, Jamelie's niece. The photo of meeting Nasser is behind her on the small screen, as well as blown up on the wall of the gallery. Again and again, this agent of rememorating history, this little girl, turns her back and enters the picture in the picture, though the superimposition is never adequate. Again and again she moves forward and reads the lines.

The ethnic American-who is the nonethnic American?-has her face turned back and front. She must understand the place of origin as politically present without her. She must also speak that politics to the metropolis, in the words censored in that other space, but translated into the metropolitan language. The child reads an adaptation into English. The child as agent is reading a history written elsewhere; this too is the politics of culture and translation, the fabrication of a strong identity. The child as agent of reading a history written elsewhere for this space, the proper pronunciation for the big words prompted by the artist's audible 


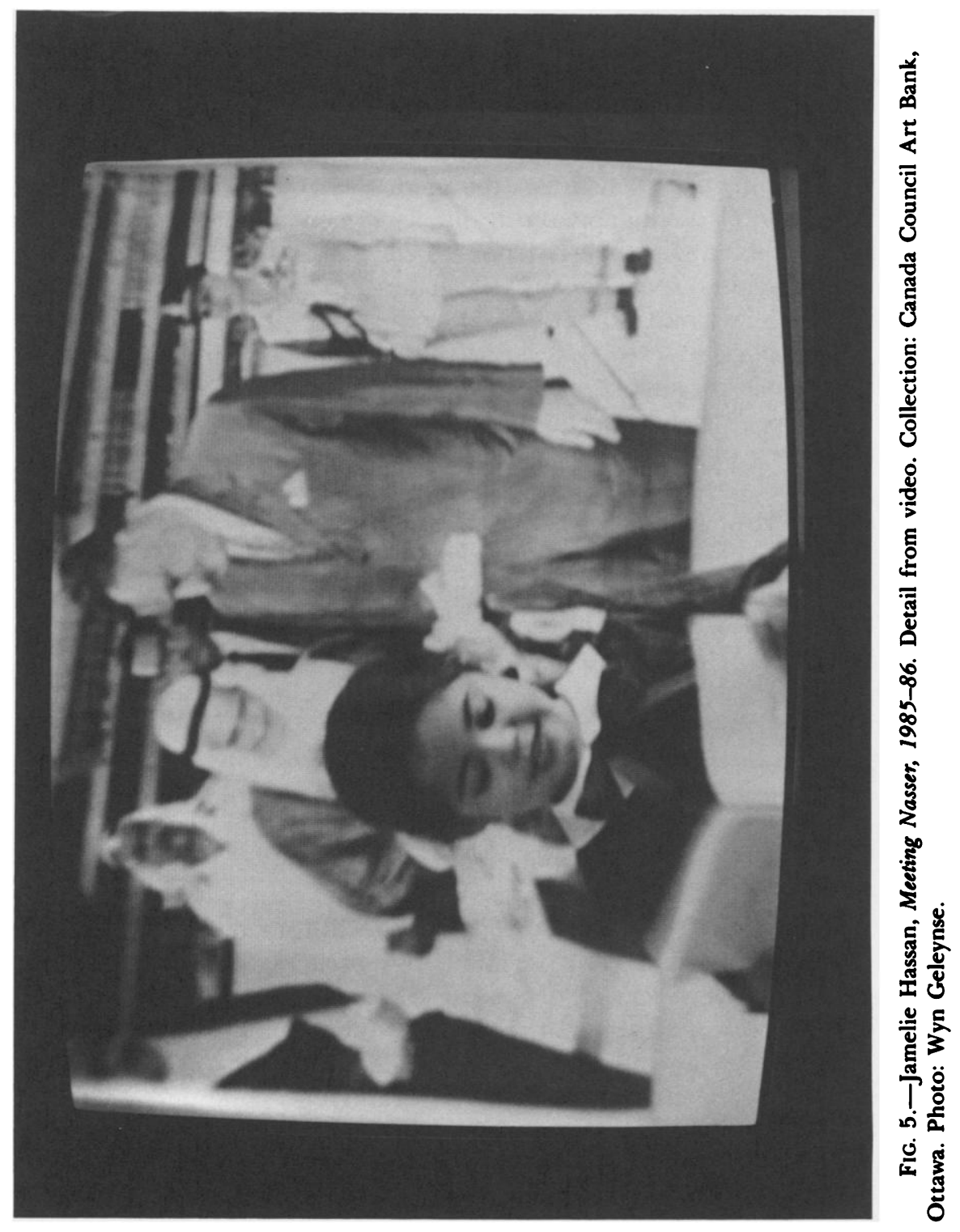

This content downloaded from 128.59.161.126 on Fri, 13 Mar 2015 18:12:31 UTC All use subject to JSTOR Terms and Conditions 
whispers (in the installation there is a soundtrack): "imagination," as she is stumbling; "event"; "mysterious."

This is a much more complex and overdetermined scenario than claiming Otherness. But the agent of history has her own lesson to teach: it is a lesson about learning. After "an act of liberation," says Michel Foucault, learning "the practices of liberty." ${ }^{15}$ Little Elizabeth Hassan tells her artist foremother confidently why she still needs prompting. She says she can still only read big letters, in English of course. She has stepped off the staged origin. She is a Canadian, the agent of new Canadian history.

I want to dwell on this apparently minor moment about the size of letters in this exhibit about the written word entitled Inscription. The child, as reader of writing, speaks again and again of the size of letters on the electronic stage: a simulacrum of the opening-up of history, for the telematic hyperreal small screen has speeded up the tempo of the translation of cultures since the mid-seventies.

It is interesting that she might be making a mistake. She might be meaning the size of words. This measure of the unit of learning, even mistaken, by the child who is learning the size of letters may be the place of the techne or art of art and history. We learn identity letter by letter. The child's repetitiveness in the work of art "makes the expert speak [-without repetition-the expert] who will not take long to say" the work "speaks" the texting of history. ${ }^{16}$ I speak too quickly: she is learning, letter by letter. What is it to learn?

If we believe that we can restore the personal, political, historical, and cross-cultural truth of art, we are silenced by the child apprentice in cultural politics as art and the performance of life: the new immigrant. The great divide between the mother and child, the mother and daughter, in the new immigrant family, is one of the most instructive things to meditate on for any student of cultural politics. We on the outside, on the other hand-somewhat older immigrants in the intellectual scene-if we believe we can restore the personal, political, historical, cross-cultural truth of art, we are silenced by the child apprentice in the art of history, who reminds us that we learn the inscription of identity letter by letter.

Therefore one must think of restitution, not of truth in art, peinture, but size, pointure. I am referring to Derrida's long piece on the debate between Heidegger and Schapiro about a Van Gogh painting, which is called precisely "vérité en pointure." The installation is becoming a case. One must think, then, of restitution, not of truth in art, peinture, but of size, pointure. One must think of restitutions of truth to size, which means,

15. See Michel Foucault, "The Ethic of Care for the Self as a Practice of Freedom: An Interview," trans. J. D. Gauthier, in The Final Foucault, ed. James Bernauer and David Rasmussen (Cambridge, Mass., 1988), p. 3.

16. Jacques Derrida, "Restitutions of the Truth in Pointing [pointure]," The Truth in Painting, trans. Geoff Bennington and Ian McLeod (Chicago, 1987), p. 314. 
in this case, the number of stitches. The painting in question is Van Gogh's Old Shoes with Laces. And size is the number of stitches in a shoe or a pair of gloves. "But truth," and this is Van Gogh, "is so dear to me . . that indeed I believe, I believe I would still rather be a cobbler than a musician with colors." 17

Restitutions of truth to size of letters. How different to learn the agency of reading the borrowed script of history by the new immigranthow different it is from talking about learning, or being grounded in an ethnic reality.

The other kind of emphasis on being a new American is not at all so benign. It is what is called, these days, "border culture." This stops the easy traffic in ethnicity where the sign system in use, English, belongs to the master. Here are some words from "Border Notebook" by Guillermo Gomez Peña, the Chicarrican artist from Tijuana-San Diego:

I dreamt the U.S. had become a totalitarian state controlled by satellites and computers. I dreamt that in this strange society poets and artists had no public voice whatsoever. Thank God it was just a dream. In English. English only. Just a dream. Not a memory. Repeat with me: Vivir en estado del sitio is a translatable statement; to live in a state of siege es suseptibile de traduccion. In Mexican in San Diego, in Puerto Rican in New York City, in Moroccan in Paris, in Pakistani in London. Definitely, a translatable statement. Vivir en estado de alerta is also translatable, my dear. To live in a state of alert, with your wings ready to flap and your eyes ready to question. Why? Why? A child of the Mexican crisis, a new foreigner in the art world, out to exhibit his wounds in immaculate neon coffins. Why? Why? Why? Why? Why? Why? San Diego Channel 10. Super Mojado loses his cool in middle of an interview. The producers are crapping their pants. Yeah. ${ }^{18}$

I wrench together this anguish with a short passage from Toni Morrison's Beloved, the most extreme example of the withholding of translation. Let us look at the scene of the mother tongue changing from mother to daughter, the institution of a culture that will yield Toni Morrison. (We have to remember that chattel slavery is matrilineal.) The scene in the novel is not of a change, but a loss. For the narrative is not of immigration but of slavery. Sethe, the central character of the novel, remembers "what Nan"-her mother's fellow slave and friend- "told her she had forgotten, along with the language she told it in. The same language her ma'am spoke" — the African language- "and which would

17. Quoted in ibid., p. 255.

18. Guillermo Gomez Peña, performance tape. 
never come back. But the message-that was and had been there all along." 19

Yet the representation of this message, as it passes through the forgetfulness of death, to Sethe's ghostly daughter Beloved, is of a withholding. Morrison writes, "This is not a story to pass on" ( $B$, p. 275). Even between mother and daughter, a certain historical withholding intervenes. If the situation between the new immigrant mother and daughter-when the mother talks protecting honor and the daughter talks reproductive rights - if this situation provokes the question as to whether it is the birth or death of translation, here the author represents, with violence, a certain birth in death.

A death in the birth of a story that is not to translate or pass on. Strictly speaking, therefore, an aporia or unbridgeable gulf. And yet it is passed on, with the mark of untranslatability on it, in the bound book Beloved that we hold in our hands. The most extreme case.

Contrast this case with one's confidence in accessibility in the house of power, ministry of culture, or official feminism, where history is waiting to be restored. The scene of violence between mother and daughter reported and passed on by the daughter Sethe, a former slave, to her daughter Denver, who carries the name of a white-trash girl in partial acknowledgement of women's solidarity in birthing, is the condition of impossibility of the book Beloved. It celebrates its own impossibility in this tragic way. Here is Sethe telling the story of that impossibility to her daughter: "She picked me up and carried me behind the smokehouse"her slave mother whose language she could no longer speak:

Back there she opened up her dress front and lifted her breast and pointed under it. Right on her rib was a circle and a cross burnt right in the skin. She said, "This is your ma'am. This," and she pointed. . . "Yes Ma'am," I said. "But how will you know me? . . . Mark me, too," I said. ...

"Did she?" asked Denver.

"She slapped my face."

"What for?" [the daughter now asks this mother] p. 61]

"I didn't understand it then. Not till I had a mark of my own." $[B$,

That would of course be a different mark because the owner is different. This scene, of claiming the brand of the owner as my own, is what we are talking about. On the other side is a resistance that cannot speak itself as resistance. An example, if the reader's attention span is long enough, of radical monstration, idamvāda undoing ahamvāda.

This scene, of claiming the brand of the owner as my own, to create in

19. Toni Morrison, Beloved (New York, 1987), p. 62; hereafter abbreviated $B$. 
this broken chain of marks owned by separate white male agents of property an unbroken chain of rememory in enslaved daughters as agents of a history not to be passed on, is of necessity more poignant than, let us say, the wonderful Creole writer J. M. Coetzee's novel Foe, where Friday, the slave whose tongue has been cut off, actually writes something on his slate, "on his own," when the metropolitan anticolonial white woman wants to teach him writing. And when she, very anxious, wants to see it, he withholds it by rubbing it off, idamvāda as erasure. ${ }^{20}$ And yet even Morrison's powerful staging, in a U.S. text in the tradition of the novel, is productive in a mode that the washed-up coastline of the southeastern edge of Bangladesh, the northern edge of the landmass off the coast in which youthe Singaporeans, if you've lost track of this identity-traffic-so successfully inscribe yourself, cannot share. Yet, I can hope, like Djebar's autobiographer-heroine Isma, to earn the right to be an ephemeral storyteller of this episode and arouse curiosity about the remote ancestors of the U.S. task force.

The scene in Beloved passes between mother and daughter and then the mother withholds the passing of it-because of course she cannot mark her child. In slavery and less extremely in migrancy, the dominant mark must be made by the master in order to be claimed as "my mark." The speaking in English in Meeting Nasser, the child turning forward and speaking in English-that mark is not given by the mother who speaks Arabic. This precarious moment in the scene of cultural translation, when it is suppressed or ignored, produces at the other end the performance of today's war, or the uncaring gift of the task force. This precarious scene of claiming the brand of the owner as my own, to create in this broken chain of marks owned by separate white male agents of property, an unbroken chain of rememory in enslaved daughters, teaches us the lesson that we must, as agents, claim that mark as Elizabeth Hassan is doing, as in a much more violent moment the slave mother is doing, as Guillermo Gomez Peña is doing. It is not a gift to be given. It is not a gift that you give at the end of a gun, or off a helicopter, and the other accepts with victory signs or an abject letter.

The lesson of the impossibility of translation in the general sense, as Toni Morrison shows it, readily points at absolute contingency. Not the sequentiality of time, not even the cycle of seasons, but only weather. Listen to this incredible passage and quietly relate this to the tedium of my first case: "By and by, all trace is gone. And what is forgotten is not only the footprints but the water too and what it is down there. The rest is weather. Not the breath of the disremembered and unaccounted for, but

20. For a longer discussion of this, see Spivak, "Versions of the Margin: Coetzee's Foe reading Defoe's Crusoe/Roxana," in Theory and Its Consequences, ed. Jonathan Arac and Barbara Johnson (Baltimore, 1990), pp. 171, 173. 
wind in the eaves, or spring ice thawing too quickly. Just weather" $(B, \mathrm{p}$. 275).

That too is time. Geological time, however slow, is also time. One must not make history in a deliberate way. One must respect the earth's tone. One might be obliged to claim history from the violent perpetrator of it in order to turn violation into the enablement of idamva $d a$, but that is another story. After the effacement of the trace, there must be no project for restoring the origin. That is "just weather," here today as yesterday.

With this invocation of contingency, where nature may be the great body without organs of woman (that passage of Marx again), we can begin to see that the project of translating culture within the politics of identity is not a quick fix.

I want now to come to my closing case, both inside and outside whatever it might be a case of. I want now to read a little bit from Jacques Derrida's Glas.

When I talk about the postponement of eco-logic by positing land as the $d a$ of $d a-\operatorname{sein}$, or of the border art where Gomez Peña goes back and forth from Tijuana to San Diego, where Jamelie Hassan goes back and forth from the Islamic world to the world of eastern Canada, where Toni Morrison crosses through slavery from Africa into the United States-for this, the word Derrida would offer us is navette, a shuttle.

The book Glas is a kind of typographic miming. It is written in bits and pieces. On the left-hand side is the homoerotic traditional tale of Western philosophy, on the right-hand side the criminal male homosexual Jean Genet. As we read, we are obliged to be a navette between the two sides in order to find out what every extraordinary page might mean. Is this also the effort to learn a case of the institution or a historicogeographical moment in gay culture, a culture that cannot speak? "Navette is the word. . . . The word-la navette-is absolutely necessary. It will have had to be there.... It concerns a small metal vessel in the form of a boat. ... And then the weaver's navette... . coming and going woven in a chain. The weave is in the navette. . . Isn't elaboration [Derrida is using it in the expanded sense-elaborare, to work out] a weaver's movement?"21

But then Derrida stops. In Derrida's early work the text is one of the master metaphors: the text as textile, through the Latin texere, to weave. But here, in mid-Derrida-and Derrida's later work is again different-he temporarily gives up the metaphor of the text. The weaver's shuttle, the navette smoothly going back and forth between the two sides is not going to serve here.

The question/statement (half a quote from Genet) with which Glas begins, in the right-hand column, is: "what remained of a Rembrandt torn into small, very regular squares and rammed down the shithole' is divided in

21. Derrida, Glas, trans. John P. Leavey, Jr., and Richard Rand (Lincoln, Nebr., 1986), pp. 207-8; hereafter abbreviated $G$. 
two" $(G$, p. 1). What remains, what is the essence of art, or of identity, when it is torn up into a million ID cards and stuffed into English, divides (at least) into two. You cannot say that the result is a smoothly woven text: "Yet we have mistrusted the textile metaphor. This is because it still keeps ... a kind of ... naturality, primordiality, cleanliness [propreté]. At least the textile metaphor is still more natural, primordial, proper than the metaphor of sewing, of the seam [couture]" (G, p. 208). Couture carries the echo of the coupure or cut-the cut from the place of origin.

Derrida is learning this lesson by looking at the gay man's text. We are in the house of identity: what is the name of (the straight white) man? In the left-hand column Hegel is accusing Kant of being a fetishist because he does not introduce love into religion; and Freud is launching the fetish into indeterminacy by genuinely speculating with it. Again and again Derrida puts in Glas texts on the so-called African fetish found in Hegel to show that these people have not earned the right to speak of the fetish. The withheld translation of Africa has been suppressed (see $G$, pp. 207-11).

For Hegel the fetish is an animal substitute for the Eucharist: this notion is implicit when Hegel, Marx, and Freud use the fetish as an accusing concept in their text, even though Freud does unmoor it. For the notion of the fetish, it will not do simply to weave a navette between Marx, Hegel, Freud, Kant. Derrida is going to have to cut holes and put their fantasy of the African fetish, which one cannot restore in a text written in English, into French. He is going to have to patch it on the text to see what difference it makes.

Meanwhile, on the right-hand side Genet is in the harem of transvestites and criminal gay men. They are putting on all kinds of fétiches, dildos, grape clusters on the crotch, et cetera, as that text unfolds. Who is the authority for whom, and how is the navette, shuttling from Hegel and company to Genet and his accomplices, weaving anything at all? Derrida suggests that we will have to think now, rather than of textile - a weave-as in the old dispensation, of the kind of sewing and patching that betrays, exposes what it should hide, dis-simulates what it signals, makes the TV screen crap its pants.

Therefore he can do nothing other than cite: "Cit[ing], as perhaps you have just seen: only to displace the syntactic arrangement around a real or sham physical wound that draws attention to and makes the other be forgotten. ... All the examples stand out, are cut out [se découpent] in this way. Regard the holes if you can" ( $G$, pp. 215,210$)$.

This is not postmodern practice. There is none of that confident absolute citation where what is cited is emptied of its own historical texting or weaving. This is a citing that invokes the wound of the cutting from the staged origin. I harmonize with Djebar here: autobiography is a wound where the blood of history does not dry. Postmodernist practice 
manages the crisis of postmodernity — the end of the dream of modernization as the imperialist dream.

Where is the crisis of identity managed? If the rhetoric of woman's body and the claims of man's logic are both in shreds, if women and men in harems are subversive of identity, is there any comfort to be found? Is it only the abstraction of the law that must assume that all human beings are one? Is it all only "the blind spot of an old dream of symmetry?"2

To strain against these questions, Derrida breaks decorum. Derrida considered Joyce with Husserl, many years ago; and has more recently written on Joyce's Molly. ${ }^{23}$ However deep he dives, Joyce's world is irreducibly gendered; Molly and Leopold digest separately. Anna Livia Plurabelle and H.C.E. remain distinguishable.

An unemphatic moment of embarrassing naïveté gives me another hint of the limits of ontology. The dream of a fundamental ontology is to precede cultural identity, but we know how much, in Heidegger's case, that dream was compromised by convictions of the special place of Greek and German. If we move from the mind to the body, the reproductive system is so thoroughly compromised in patriarchy that it will not show us a way out. In Glas Derrida circles around the question of the family, the mother, male homosexuality, the double bind of tumescence (in French, bander or to bind) and makes visible the inflexibility of this limit. Antigone is the only daughter there, and, in his problematic book around female homosexuality, he can claim nothing but a problematic droit de regard or right to watch. ${ }^{24}$

The digestive system is deeply, culturally marked. What are the limits to ontology here? Glas on the right-hand side starts with the shithole, as I have already remarked. The outer limits to Kant's sublime were long ago located in vomit. ${ }^{25}$ Derrida's current work, once again around the Eucharist and that assimilated Creole Augustine, obstinately asks: "What is it to eat?" In this unemphatic moment in Glas, Derrida asks a question that causes embarrassment. I cannot include it in my staging of the fragments of identity-talk: Derrida's practice does not share in that crisis management.

Derrida suggests that the text, which was the privileged metaphor in his earlier dispensation—and will not be discarded-is a navette between

22. Irigaray, "The Blind Spot of an Old Dream of Symmetry," Speculum of the Other Woman, trans. Gillian C. Gill (New York, 1985), pp. 11-29.

23. See Derrida, "Ulysses Gramophone: Hear Say Yes in Joyce," trans. Tina Kendall and Shari Benstock, in Acts of Literature, ed. Derek Attridge (New York, 1992), pp. 256-307.

24. See Derrida, afterword, in Marie-Françoise Plissart, Droit de regards (Paris, 1985). $3-25$.

25. See Derrida, "Economimesis," trans. Richard Klein, Diacritics 11 (Summer 1981): 
Geist and Gäschen, between spirit and a fart, between the transcendent breeze and the wind that makes us embarrassed, which is marked by the body's materiality. Genet is talking about roses shooting whiff after whiff at our faces (the rose is a character in this gay brothel)-and Derrida, in the middle of one of these passages, comments, "The essence of the rose is its nonessence: its odor insofar as it evaporates. Whence its effluvial affinity with the fart [pet] or the belch: these excrements do not stay [se gardent], do not even take form" (G, p. 58). Fart in French is pet, so to repeat identically, absolute translatability becomes ré-peter, each fart different because of what the body must take in to live. A familiar case of the daily failure of the simplicity of ontology. Rather than the idea infinitely repeatable and therefore always identical, the repetition becomes something that cannot be caught. "How could ontology lay hold of a fart?" $(G$, p. 58). He rewrites the ontico-ontological difference by reminding us of the body's being: the ontic, which in Heidegger is the intimacy of being, to which the being is so proximate or close that no ontology can lay hold of it, in the late Heidegger becomes a certain kind of fetish. His politics change, he invokes an originary or primordial language.

What Derrida is looking at is the way we are when we are close to ourselves. This lecture - in Singapore-would have been an exercise in the discomfort of controlling flatulence if it had been an after-dinner lecture. And when one is alone and proximate to oneself, one finally gives way to the totally unembarrassing comfort of the signature of the body being itself (as it were) - nobody there to be embarrassed or repelled. It is simply the end of the public sphere, for the moment. It is really very difficult to hear this question: How can ontology-the philosophy of being-lay hold of a fart? There is none of the glamor of sexuality here, or of the so-called spectrum of sexual practices. How can ontology lay hold of a fart? An ontology can always put its hand on whatever remains in the john-the shit-but never on the whiffs let out by roses. So the text is a gas, the mark of the spirit in one's body. The text is an imperfect navette between Geist and fermentation, Gäschen, the little gas. The ontic as fart or belch, the signature of the subject at ease with itself decentered from the mind to the body, which writes its inscription. This also is the level at which war has no meaning, and indeed the embarrassment often offered by the subaltern victim in the flesh, scratching herself and picking her nose.

In this version of the ontic as such, to go back to the same bit of Marx, "to say that the human being's physical and mental life is linked to nature simply means that nature is linked to itself," breathing in and out, as it were. ${ }^{26}$

Marx puts it in the language of classical German philosophy, which Derrida takes to its limit. On that ground, there is no importance of any-

26. Marx, "Economic and Philosophical Manuscripts," in Early Writings, p. 328. 
thing. But if you cannot catch it, how can ontology lay hold of it? This is not as glamorous as either mind or body, high-toned mind-talk or the highly attitudinizing body-talk; it is none of that. There is crisis, there is the long-haul politics of culture, but this rag-and-bone shop remains the counter-case of cultural institution, of indeed the philosophy of Being, highest talk of identity.

It is not possible to remain here. Zoom now to the other end of the spectrum. We have considered varieties of Creole and migrant art and theory, writing by a woman who takes the history of slavery seriously, responsibly, art and theory that try to cope with the problem of the politics of translation, the politics of culture, the politics of identity.

Now let us touch on the responsibility of the "national" artist seeking an international audience. I'm not speaking of the artist who is an immigrant, but the artist who has remained in decolonized space to represent that culture to the persons in metropolitan space eager for other cultures. This is a great narrative indeed, and upon this register I think that the national artist has a very strong responsibility not to take advantage of the sanctioned ignorance of the West.

Recently in Italy I saw a performance by a woman, an Indian artist, a dancer, which was broken up by an Italian director. What he was actually doing onstage (I was reminded of Olympia in Hoffmann's story, Freud's treatment of "The Sand-man") was actually making her do her classical dance and then asking her to break up her sequences, taking away her music, and then slowing the sequences down as much as possible, making her do 5 percent of the sequence and then putting other women-whom he no doubt treats the same way-together so they could do a peculiar kind of a dance together under his control. And in the representation of this happening - which filled me with terror, because that is how we were produced by assenting to imperialism-at a certain point, he makes her say that she had resisted him for a long time until she realized that he was not going to take away her style. When questioned by Trinh T. Minh-ha, as to how she believed that he would not take away her style she said confidently, he promised me nothing. I believed him.

We are afraid of this kind of seductive winning of the assent of the colonized, so that the result is a kind of ventriloquism that then stands in for free will. Our own complicity in our production is another kind of translation of cultures, access to a "museumized" identity, roots in aspic. The national artist in the Third World has a responsibility not to speak for the nation in response to a demand made by this craving for intercultural exchange. Everything is susceptible to exchange; but commodity is something made for exchange. Identity as commodity.

And so I would like to turn to the film The Voyage Beyond, by the Bengali filmmaker Gautam Ghosh. This is not a film about contemporary 
India, but of India in the last century. It is the story of a very young girl being married off to a dying old man. They are in a burning ghat on the borders of the Ganges or Ganga. At a certain point the outcast, the Untouchable, wins her to sexuality. She is there because she's going to be sati, a widow who self-immolates. At the end, she is washed away in the waves of the Ganga, as is her dying husband.

This is basically the story. Actually the film engages in a peculiar species of auteurism by borrowing the proper name of a magisterial text of Bengali fiction, Kamalkumar Majumdar's Antarjalīyatrā (1961). The metropolitan viewer cannot know this. The result, in this particular case, is a sort of violation of the transcoding or translation between two media. (I know that films are not supposed to be faithful to novels, that is not my point.) I believe that it is this possibility of violating the particularity of this novel as historical icon that kept Satyajit Ray and Mrinal Sen from attempting its filming.

If in the context of the other cases I have said that sometimes it is necessary to withhold translation, as in the extreme case staged by Toni Morrison, here, turning 180 degrees, I am suggesting that in certain macrocontexts there is also room for a gesture of faithfulness to the original, if it is to be a faithfulness to the original considered as one case among many, not a case that should be idealized. In a certain historical conjuncture, when the West is avid for Third World culture, it sometimes becomes the appropriate case. Given the experimental verbal authority of this novel, no film using the title Antarjalìyatra can avoid auteurism. A new Macbeth is a new Macbeth.

I will not attempt to comment on the verbal experimentation of Antarjaliyatra. Let me, however, say a word or two about the general project of the book. It does have something to do with the question of identity. The idea of identity is often marked by the names of continents, huge chunks of the world: Asian identity, Third World identity. The author of the book attempts the nearly impossible task of grasping identity in the extremely proximate or close-up place - the place where, in postmodernity, Derrida locates the fart-where it has not yet reached the level of adjectival description. In the layer of its incessant and inchoate emergence, close to the body, if the body too is understood as a kind of shuttling, between bone and blood, nerve and twitching muscle. Kamalkumar chooses the liminal space of the burning of the body and three human beings relating differently to that event-to-come: an event that hangs over the text, but never happens. The dying brahmin, the woman in imminent death-in-life, and the Untouchable, who is the facilitator of the flame that consumes the body. Ghosh shatters this project by staging the burning ghat as a realistic referent carrying a realistic amount of local color, a stage for a broadly conceived psychodrama played out by easily grasped stock characters: the good and earthy Untouchable, the good, colonially touched doctor who is not quite good enough, the patriarchally oppressed 
woman awakening into struggling self-consciousness. Hinduism as precolonial superstition: a screen easy to work out from a base of minimal knowledge.

What the author of the novel is trying to do takes as understood a fully formed ideological subject, to whom the reader is invited to be ex-centric. In other words, Majumdar expects the reader to have enough internalized perception of a certain kind of Hinduism, as a heteropraxic cultural system, to have earned the right to be asked to consider the following question: How do the affects work when such extreme dispensations as sati and the caste system operate as a felt cultural norm? This kind of a question is extremely important today in my nation-state of origin where Hindu fundamentalism is violent, where even children and young girls are sometimes being convinced that to be a good citizen of India one has to internalize an absolute version of the majority religion, which cannot admit that it is a negotiated mistranslation. Again we have an attempt at the cultural or political translation of origins.

In this context, to redo the book for a national audience would have been quite different from doing it for an international audience. This is not the place to develop those suggestions.

Let us go back to the novel's project. His question: how do the affects work when such extreme dispensations as widow-burning and the caste system operate as a felt cultural norm? How could our mothers and grandmothers have assented to this, and remained human? There is no possibility here for the viewer to interpret the film from a position of cultural superiority. This is a question that can only be asked by us as Hindus, of ourselves. This text is exactly not for the outsider who wants to enter with nothing but general knowledge, to have her ignorance sanctioned.

Majumdar wants to avoid critical distance as far as possible because he knows it is not fully possible. He articulates the most extreme system of belief, not because he wants to give himself distance, but because he wants to acknowledge proximity, because he wants to get at that most difficult thing, perspectival normativity. In other words, he is not distancing himself by portraying these three people as "normal." He is trying to perspectivize the idea of normality as such by choosing the hardest possible case. $\mathrm{He}$ is perspectivizing all normality, yours and mine as well, not just "Asian" or "historical." And-this is a difficult point but I want to continue to emphasize it - the base of normality out of which normality in general is thus unmoored is a rather specific Bengali cultural base, a general "identity," if you like. From out of this base, presupposed only to be put under erasure, Kamal Majumdar seems to ask a question that I can, since I write in English, put to you almost exactly in the words of John P. Leavey, Jr., and Richard Rand as they have translated the French of Jacques Derrida: "How does one give the seing [a thumbprint as well as one's breast] to an affect?" ( $G$, p. 42b).

It is easy to get information about the identity of an entire continent, 
or to put one's signature on a concept, support it or oppose it. But how does one claim the normality of an affect in extremis as one's own, in the place of the seing rather than the signature? One way is to unmoor affect from the natural person and place it in ideology - can this be done except from above?

Again, this is a question that I can neither not ask nor answer. Turning away from this limit, let us notice cruder ways of fabricating identity. Let us look at the way in which Ghosh changes the introductory verbal material from novel to film.

At the beginning of the film, Ghosh's subtitle writer takes a feeble whack at giving the viewer a bit of potted history. In 1829 Lord William Bentinck abolished the self-immolation of widows, echoed by Indian names like Ram Mohun Roy in the dialogue. In the Bengali film, there is nothing but the title and the opening credits. Let us now turn to some of the sentences in the preface of the book, dealing precisely with the identity or rather the subject-position of the assigned reader or viewer: "The affectiveicon of this book is Ramakrishna's, the poetic icon Ramprasad's. . . . I am certain our country still thinks of the Ganga as its life, our country still touches immortality, everyone will understand our story. My profound respect to the reader." ${ }^{27}$

Who are these two named figures? Ramprasad Sen, an eighteenthcentury clerk patronized by Raja Krishna Chandra Sen, is not exactly a figure unknown to the West. Some of his exquisitely and deceptively simple poetry in praise of Kali was translated into French fifty years ago. He is a constituent figure of Bengali culture. He is part of that great movement of reinscribing Kali into an affective goddess, both mother and daughter, violent only out of radical innocence, not malevolent but a punisher, in sheer childlike impatience with evil. This Kali is the book's icon, not the peculiarly monstrous figure behind the Untouchable in a sequence towards the end of the film, where he is talking to the young bride, reminiscent of nothing so much as Coppola's insensitive imaging of the Bodhisatva icon in Apocalypse Now.

Ramakrishna, a mystical visionary of the second half of the nineteenth century, is another constituent figure of contemporary Bengali culture who is not unknown to the West. Centers of the Ramakrishna mission began to be established in the West from the very beginning of the twentieth century. His conversations have been translated into English. Christopher Isherwood wrote a sympathetic biography about ten years ago. He is one of the most moving affective reformers of Hinduism, attaching himself to a Kali who closely resembles Ramprasad's beloved goddess. He is a perspectivist, attempting affectively to enter the subjectivity of a Muslim, a Christian, a woman. He is absolutely opposed to the caste system. This is not the place to comment on what has happened to

27. Kamalkumar Majumdar, Antarjalìyātrā (Calcutta, 1981), p. ix. 
Ramakrishna's vision as it has become socially institutionalized. What is important for the question of the identity of the reader/viewer is that this figure is the affective icon of the book.

Majumdar writes, "the new Bengal has been created by remembering him, by keeping him in mind. He took away a bit of fear in the natural human being in the raw, from his own wakeful state by saying: 'is a human being a small thing, eh!'"28

The book's point of view is a certain Ramprasad's and a certain Ramakrishna's, without violence, without cruelty, without caste, and without addiction to flesh. Now suppose Gautam Ghosh had tried to transcode this complex micrological project into filmic idiom! Instead he appropriated, abdicated, banalized, putting the name of William Bentinck on the screen of Ramprasad Sen and Ramakrishna Paramahansa.

The Voyage Beyond is actually what is called a "topical" film. It is made in the atmosphere of great interest in sati following Rup Kanwar's selfimmolation a few years ago. Feminist mobilization and resistance to sati on that occasion was widespread. In that legalized context, it was understandably not possible to approach gendered subjectivity with any subtlety. The movement had to remain on the level of female agency. A filmic representation of woman-in-sati is not confined to such restrictions. What does Gautam Ghosh do with the relative autonomy of this art form? There are at least five looks at different points of the film that consolidate the representation of the young bride Jashobati in the film:

a) an unconsummated look before the exchange of garlands that seals the marriage;

b) a look at the temple of the grotesque goddess asking for a repetition of the sexual encounter;

c) a rounded gaze at the stone printed with the palm mark of the burnt widow;

d) a look at the end with Jashobati pinned on the woodframe evocative of the seasonal status of goddesses regularly deposited in the river;

e) the visually exciting representation of the unfocused look of the eye painted on the boat.

The least convincing bit of liberated script, "Am I your plaything?" is not accompanied by any orchestration of the gaze.

Considerations of the first three should accompany a viewing of the film. I would like to point out here that Jashobati looking out of the disposable goddess-frame and the lovely boat with the pair of eyes that cannot gaze carry a heavy cultural message without cultural logic. The suspension of two particular deaths - the natural death of the old man and the forced unnatural death of the young wife-deaths that do not happen in the novel, is here recoded as a return to a cultural base without any cultural justification. To play thus with textual subtlety seems to me to

28. Ibid. 
be an abdication of the responsibility of the national artist, trafficking in national identity (in the name of woman) for international consumption.

For it is against the grain of this responsibility of the national in the international that we feminist internationalists strain. I am thinking now of the worldwide group called Women Living under Islamic Law, extending all the way from North Africa to Indonesia with members from immigrant communities in the First World. ${ }^{29}$ These feminist internationalists must keep up their precarious position within a divided loyalty: being a woman and being in the nation, without allowing the West to save them. Their project, menaced yet alive, takes me back to my beginning. It is in their example that I look at myself as a woman, at my history of womaning. Women can be ventriloquists, but they have an immense historical potential of not being (allowed to remain) nationalists; of knowing, in their gendering, that nation and identity are commodities in the strictest sense: something made for exchange. And that they are the medium of that exchange. ${ }^{30}$

When we mobilize that secret ontic intimate knowledge, we lose it, but I see no other way. We have never, to quote Glas, been virgin enough to be the Other. Claudine Hermann, a lawyer who has practiced both in Afghanistan and in France, gives me my closing words: We have always known how [in "culture"] "to see women through the eyes of men and, in life, to see men through the eyes of women." We have always known "how wide the gap is." We have always been "schizoid and we might add . . . hermaphrodite." ${ }^{1}$ Not androgynous, but a bit of a hermaphrodite secure in the conviction that sex and gender are structurally not identical. Cultures are built violently on the enforced coercion that they are. War is its most extreme signature, and, like all signatures, patriarchal. ${ }^{32}$ Our lesson is to act in the fractures of identities in struggle.

29. See Marie-Aimée Hélie-Lucas, “Women Living under Islamic Laws," South Asia Bulletin 10, no. 1 (1990): 73.

30. See Ted Swedenburg, "Palestinean Women Now: Tradition and Difference in the 1936-39 Revolt: Implications for the Intifada," conference paper, "Marxism Now: Tradition and Difference," 2 Dec. 1989, University of Massachusetts. He makes this point for one of the most important global sites of contestation: Palestine.

31. Claudine Hermann, The Tongue Snatchers, trans. Nancy Kline (Lincoln, Nebr., 1989), p. 7.

32. For the patriarchality of signatures in identity, see Derrida on Nietzsche, "Logic of the Living Feminine," The Ear of the Other: Otobiography, Transference, Translation, trans. Peggy Kamuf (New York, 1985), pp. 3-19. It is this logic that we must ab-use as we act bits, talk identity. 